\title{
Quantitative determination of glycyrrhizinic acid by square-wave voltammetry and high-pressure liquid chromatography
}

\author{
Aneta Dimitrovska $^{1 *}$, Valentin Mircevski ${ }^{2}$, Svetlana Kulevanova ${ }^{1}$ \\ ${ }^{1}$ Faculty of Pharmacy, "Ss. Cyril and Methodius" University, Vodnjanska 17, 1000 Skopje, Macedonia \\ 2Institute of Chemistry, Faculty of Natural Sciences and Mathematics, "Ss. Cyril and Metodius" University, \\ Arhimedova 5, 1000 Skopje, Macedonia
}

Received April 2003; accepted June 2003

\begin{abstract}
Novel adsorptive stripping square-wave voltammetric method as well as a new high-pressure liquid chromatographic method for direct determination of glycyrrhizinic acid in dosage pharmaceutical preparation, used against virus infections, have been developed. Glycyrrhizinic acid is an electrochemically active compound, which undergoes irreversible reduction on a mercury electrode surface in an aqueous medium. Its redox properties were studied thoroughly by means of square-wave voltammetry, as one of the most advanced electroanalytical technique. The voltammetric response depends mainly on the $\mathrm{pH}$ of the medium, composition of the supporting electrolyte, as well as the parameters of the excitement signal. It was also observed that the voltammetric properties strongly depend on the accumulation time and potential, revealing significant adsorption of glycyrrhizinic acid onto the mercury electrode surface. Upon this feature, an adsorptive stripping voltammetric method for quantitative determination of glycyrrhizinic acid was developed. A simple, sensitive and precise reversed phase HPLC method with photodiode array UV detection has also been developed, mainly for comparison and conformation of the results obtained with the voltammetric method.
\end{abstract}

Key words: Glycyrrhizinic acid, square-wave voltammetry, high-pressure liquid chromatography

\section{Introduction}

Glycyrrhizinic acid (GA) is a saponin extracted from Glycyrrhiza glabra root. According to its chemical structure, it belongs to penthacyclical triterpenoid saponins, products of $\beta$-amyrin (1). GA and its aglycon $18 \beta$ glycyrrhetinic acid are widely used against bacterial and virus infections, also as antiflogistics, expectorants, corrigens and as components with mineralocorticoid effect (2).

Many analytical methods have been employed for the determination of GA, such as: chromatographic techniques (high-pressure liquid chromatography, thin-layer chromatography, micellar electrokinetic chromatography, gas chromatography) (3-10); electrochemical techniques (oscillopolarography, single-sweep polarography) $(11,12)$; spectroscopic methods $(13,14)$. Immunoassays (ELISA and RIA techniques) were also used for determination of the glycyrrhizinic acid (15).

\footnotetext{
* e-mail:aneta.dimitrovska@baba.ff.ukim.edu

Tell: 126 024; Fax: 123054
}

The general purpose of the work was to develop simple, precise and accurate methods for quantification of glycyrrhizinic acid in pharmaceutical dosage forms.

Adsorptive stripping voltammetry is a valuable and well-known analytical method for trace analysis of electroactive compounds capable to adsorb onto the working electrode surface (16).

In the family of pulse techniques square-wave voltammetry appears to be one of the most advanced electroanalytical techniques (17). This technique is attributed with unique advantages, such as: high frequency and amplitude, solitary approach in the current-sampling procedure, as well as the effective ability to discriminate the capacity current. Thus, for developing a particular absorptive stripping voltammetric method for determination of miscellaneous species, squarewave voltammetry is most frequently a technique of choice.

In addition to the current voltammetric method, the paper also describes a new chromatographic method for determination of GA serving mainly for comparison and conformation of the results obtained with the voltammetric method. 


\section{Experimental}

The analyzed sample was a pharmaceutical dosage in a form of spray. As declared by the manufacturer, the sample contains $0.1 \%(\mathrm{w} / \mathrm{w})$ glycyrrhizinic acid, while other components are maleic acid, fumaric acid, ascorbic acid, folic acid, polysorbate 80, propylen glycol and purified water. Glycyrrhizinic acid, standard substance, was a product of "Chemonova International, S. A." from Spain.

\section{Voltammetric method}

All used chemicals were of analytical reagent grade. KI, $\mathrm{Na}_{2} \mathrm{SO}_{4}, \mathrm{NaNO}_{3}, \mathrm{KClO}_{4}, \mathrm{KBr}$, citric acid, and $\mathrm{Na}_{2} \mathrm{HPO}_{4}$ were all Merck products. Double distilled water was used. The buffer solutions were prepared by mixing of appropriate quantities of citric acid and $\mathrm{Na}_{3} \mathrm{PO}_{4}$. The stock solution of glycyrrhizinic acid was prepared by dissolving in redistilled water.

The oxygen removal from the electrolyzed solutions was performed by purging with highly purified nitrogen for ten minutes prior each measurement, and a nitrogen blanket over the solution was maintained thereafter. The measurements were carried out at room temperature.

All voltammograms were recorded with multi-mode polarograph Princeton Applied Research Model 384 B equipped with static mercury drop electrode Model PAR 303A. The reference was $\mathrm{Ag} / \mathrm{AgCl}$ (sat. $\mathrm{KCl}$ ) and a platinum wire was used as a third electrode. A small mercury drop with a surface of $0.0147 \mathrm{~cm}^{2}$ was used as a working electrode.

The other experimental conditions are indicated in the caption of the figures.

\section{HPLC method}

All used chemicals were HPLC grade. The chromatograms were recorded on Waters HPLC system, equipped with Pump Waters 600 E, sample injector Rheodyne 7725i with $20 \mu 1$ loop, Photodiode Array Detector 996 and column oven. Glycyrrhizinic acid was separated on a $5 \mathrm{~mm}$ Symmetry C18 column ( $25 \mathrm{~cm} \times 4.6 \mathrm{~mm}$ i.d.) operated at $35{ }^{\circ} \mathrm{C}$, using $25 \mathrm{mM}$ potassium dihydrogen phosphate $(\mathrm{pH} 2.2)$ / acetonitril (60: $40 \mathrm{v} / \mathrm{v})$ as a mobile phase (and solvent) at a flow rate of $1.6 \mathrm{ml} / \mathrm{min}$ and detection at 251 $\mathrm{nm}$. The chromatographic system was controlled by software program Waters Millennium 32.

\section{Results and discussion}

\section{Determination of glycyrrhizinic acid by voltammetric method}

Glycyrrhizinic acid is both electroactive and surfaceactive compound. Its undergoes totally irreversible reduc- tion onto the mercury electrode surface. Under conditions of square-wave voltammetry, the response consists of a single well-defined peak at potential of about $-1.50 \mathrm{~V}$ as represented in Fig. 1. The SW voltammograms were analyzed for the peak position, height, and half-peak width. All these properties of the voltammetric responses are strong function of $\mathrm{pH}$ and chemical composition of the medium, accumulation time and potential, as well as the parameters of the excitement signal.

The redox reaction of GA could be measured only within the $\mathrm{pH}$ interval from 2.0 to 8.0. Beyond these boundaries, no voltammetric response could be detected. In strong acidic medium $\mathrm{pH} \leq 2$, the hydrolysis of GA occurs at appreciable rate (18) preventing its electrochemical detection. As $\mathrm{pH}$ increases from 2.0 to 4.9, the SW peak shifts slightly towards potential that is more negative (see data in Table 1). At the same time, the peak current depends non-linearly on $\mathrm{pH}$, crossing through maximum value at about $\mathrm{pH}=3.8$. Within the interval $5.4 \leq \mathrm{pH} \leq 7.5$, the SWV response of GA splits in two peaks indicating existence of two different redox reactions. For analytical purposes, this phenomenon is strongly unfavorable.

The complexity of the $\mathrm{pH}$ effect upon the voltammetric response arises from the complexity of the redox reaction of GA as well as the complexity of its adsorption process onto the working electrode surface. Nevertheless, the electrolyte solution with $3.8 \leq \mathrm{pH} \leq 5.0$ provides a save medium for analytical application, as the SWV response in those solutions consists of a well-defined single peak. Moreover, the ratio $I_{\mathrm{p}} / \Delta E_{\mathrm{p} / 2}$ (where $I_{\mathrm{p}}$ and $\Delta E_{\mathrm{p} / 2}$ is a peak current and half-peak width, respectively) should serve as a main criterion for selecting an optimal response for analytical purposes. This quantity reaches a maximum value for $\mathrm{pH}=4.7$ revealing that this medium is the most suitable for quantitative determination of GA.

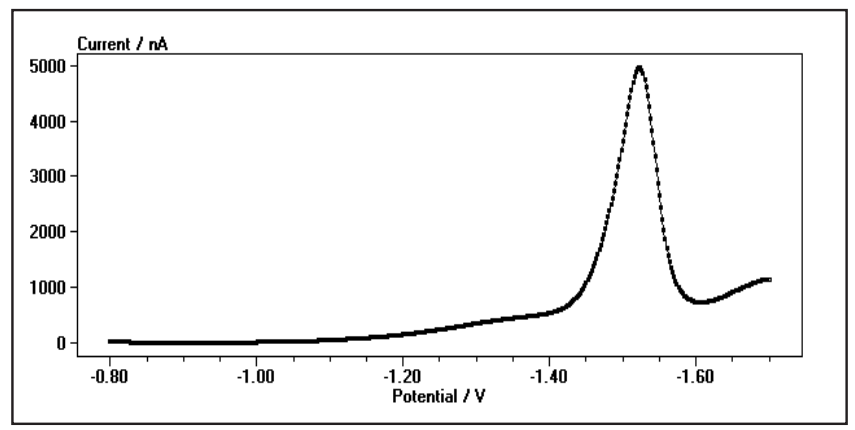

Fig. 1. Square-wave voltammogram of $1 \times 10^{-5} \mathrm{~mol} / \mathrm{L}$ glycyrrhizinic acid solution recorded in $0.1 \mathrm{~mol} / \mathrm{L} \mathrm{KI}$ electrolyte solution buffered to $\mathrm{pH} 4.7$. Other experimental conditions are: initial potential $E_{\mathrm{s}}=-0.3 \mathrm{~V}$, final potential $E_{\mathrm{f}}=-1.7 \mathrm{~V}$, accumulation time $t_{\mathrm{acc}}=100 \mathrm{~s}$, accumulation potential $E_{\text {acc. }}=-0.3 \mathrm{~V}, \mathrm{SW}$ frequency $f=100 \mathrm{~Hz}, \mathrm{SW}$ amplitude $E_{\mathrm{sw}}=25 \mathrm{mV}$ and increment $\mathrm{d} E=4 \mathrm{mV}$ 
Table 1. Dependence of peak potential and peak current of the voltammetric response of $5 \times 10^{-6} \mathrm{~mol} / \mathrm{L}$ glycyrrhizinic acid solution on $\mathrm{pH}$ recorded in citrate buffers. The other experimental conditions were: $f=100 \mathrm{~Hz}, E_{\mathrm{SW}}=25 \mathrm{mV}, \mathrm{d} E=2 \mathrm{mV}, E_{\mathrm{S}}=-0,8 \mathrm{~V}$ and $\mathrm{Ef}=-1.7$.

\begin{tabular}{ccccc}
\hline \hline $\mathrm{pH}$ & $E_{\mathrm{p}, 1} / \mathrm{V}$ & $E_{\mathrm{p}, 2} / \mathrm{V}$ & $I_{\mathrm{p}, 1} / \mathrm{nA}$ & $I_{\mathrm{p}, 2} / \mathrm{nA}$ \\
\hline 2.0 & \multicolumn{4}{c}{ No voltammetric response } \\
3.6 & -1.476 & & 603.7 & \\
3.8 & -1.478 & & 1183 & \\
4.1 & -1.486 & & 343.4 & \\
4.3 & -1.476 & & 443.6 & \\
4.5 & -1.502 & & 255.5 & \\
4.7 & -1.496 & & 309.5 & \\
4.9 & -1.506 & & 372.4 & \\
5.4 & 1.414 & -1.494 & 556.7 & 773.7 \\
6.1 & -1.37 & -1.45 & 159 & 172 \\
6.8 & -1.358 & -1.464 & 273.7 & 306.4 \\
7.5 & -1.382 & -1.456 & 144.6 & 153.9 \\
8.0 & No voltammetric & \multicolumn{3}{c}{ No voltammetric } \\
& response & \multicolumn{3}{c}{ response } \\
\hline
\end{tabular}

Generally speaking, the adsorption of an electroactive compound onto the electrode surface is affected primarily by the chemical composition of the medium and the accumulation potential (16). The accumulation of GA on the mercury electrode surface was studied in four diverse supporting electrolytes. The results for the peak currents are listed in Table 2.

As it can be seen, the highest currents were obtained in $0.1 \mathrm{~mol} / \mathrm{L}$ solution of $\mathrm{KI}$ indicating that in this medium the adsorption occurs at highest rate. Keeping in mind that the iodide ions are themselves adsorbed on the electrode surface, one can conclude that GA exhibits substantial tendency for adsorption. The data presented in Fig. 2 support this assumption. The Figure 2 illustrates the effect of the accumulation time upon the peak currents of GA investigated at various concentrations of the analyte. By increasing the accumulation time, the peak current becomes higher and the entire $I_{\mathrm{p}}-t_{\mathrm{acc}}$ relationship obeys a low of an isotherm. The appear plateaus

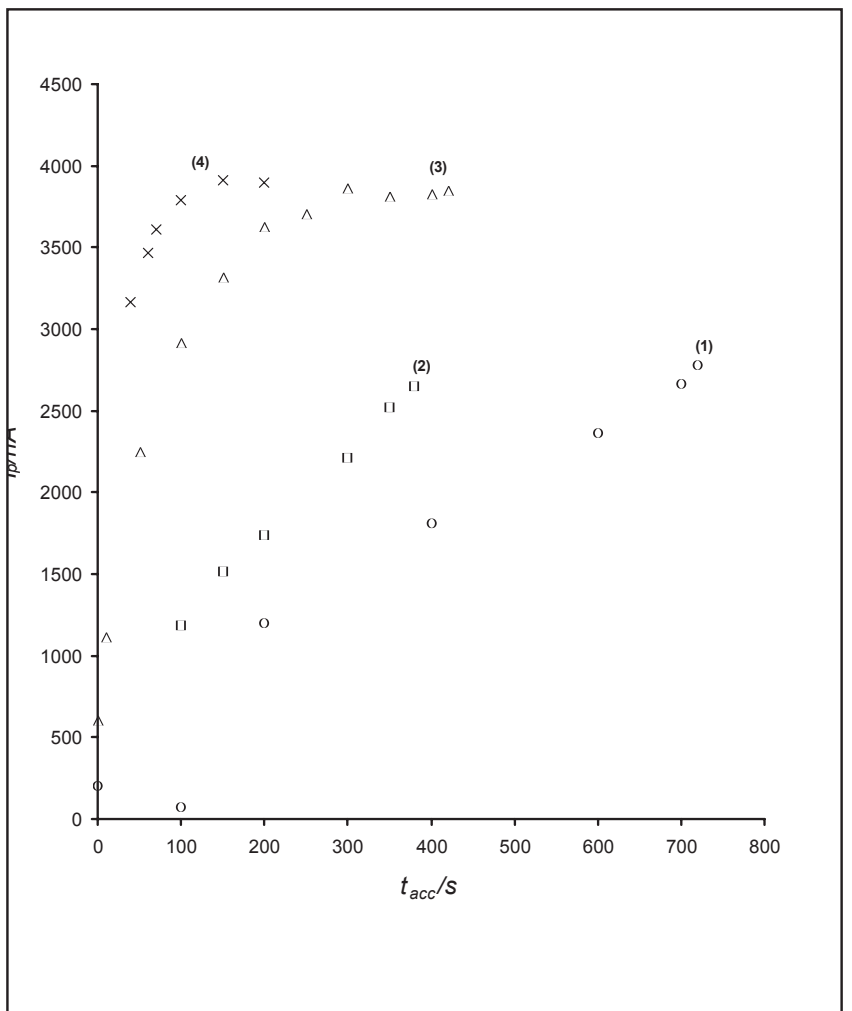

Fig. 2. Dependence of the peak currents on the accumulation time for different glycyrrhizinic acid concentration recorded in $0.1 \mathrm{~mol} / \mathrm{L} \mathrm{KI}$ buffered to $\mathrm{pH}=4.7$. Experimental conditions were: $E_{\mathrm{acc}}=-0.8 \mathrm{~V}, f=100 \mathrm{~Hz}$, $E_{\mathrm{sw}}=25 \mathrm{mV}, \mathrm{d} E=2 \mathrm{mV}$ and $c$ (glyc. $)=5 \times 10^{-7}(1)$, $1 \times 10^{-6}(2), 5 \times 10^{-6}(3) 1 \times 10^{-5} \mathrm{~mol} / \mathrm{L}(4)$.

of the curves 1 and 2 corresponds to the saturation of the electrode with electroactive material. For analytical purposes, the electrode should be covered by a monomolecular layer of deposited GA molecules, which is fulfilled within the linear portions of the isotherms.

The influence of the accumulation potential on the peak current is presented in Fig. 3. The accumulation potential affects considerably the entire accumulation process through its influence upon the structure of the electric double layer adjacent to the electrode surface (16). The peak current depends sigmoidally on the accumulation potential in a form of a pseudopolarogram.

Table 2. Dependence of peak current of $5 \times 10^{-6} \mathrm{~mol} / \mathrm{L}$ glycyrrhizinic acid solution on the accumulation time recorded in diverse supporting electrolytes. Experimental conditions were: $f=100 \mathrm{~Hz}, E_{\mathrm{sw}}=25 \mathrm{mV}, \mathrm{d} E=2 \mathrm{mV}, E_{\mathrm{acc}}=-0.8 \mathrm{~V}$. All supporting electrolytes were buffered with citrate buffer to $\mathrm{pH}=4.7$.

\begin{tabular}{ccccccc}
\hline \hline & $I_{\mathrm{p}} / \mathrm{nA}$ & $I_{\mathrm{p}} / \mathrm{nA}$ & $I_{\mathrm{p}} / \mathrm{nA}$ & $I_{\mathrm{p}} / \mathrm{nA}$ & $I_{\mathrm{p}} / \mathrm{nA}$ & $I_{\mathrm{p}} / \mathrm{nA}$ \\
\hline$t_{\text {acc }} / \mathrm{s}$ & $\mathrm{Na}_{2} \mathrm{SO}_{4}$ & $\mathrm{NaNO}_{3}$ & $\mathrm{KClO}_{4}$ & $\mathrm{KI}$ & $\mathrm{KBr}$ & Citrate buffer \\
\hline 0 & 431.9 & 395.5 & 436.4 & 562.9 & 425.9 & 446 \\
50 & & & & & 2323 \\
60 & 2329 & 2099 & 2272 & 2839 & 2485 & 3298 \\
100 & 3396 & 3190 & 3264 & 3862 & 3272 & \\
120 & & & & & \\
\hline
\end{tabular}




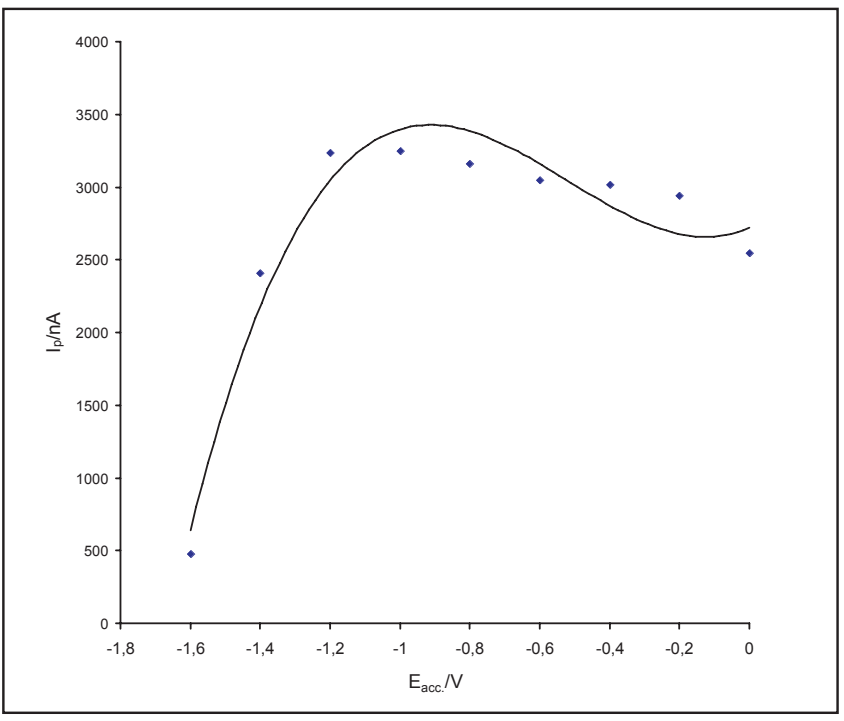

Fig. 3. Dependence of the peak current of glycyrrhizinic acid on the deposition potential. Experimental conditions were: $f=100 \mathrm{~Hz}, E_{\mathrm{S}}=-0.8 \mathrm{~V}, E_{\mathrm{sw}}=25 \mathrm{mV}, t_{\mathrm{acc}}=15 \mathrm{~s}, \mathrm{~d} E=2 \mathrm{mV}$, $c$ (glyc.) $=5 \times 10^{-6} \mathrm{~mol} / \mathrm{L}$, supporting electrolyte $0.1 \mathrm{~mol} / \mathrm{L} \mathrm{KI}$ buffered to $\mathrm{pH} 4.7$.

The peak current decreases considerably as the accumulation potential becomes more negative than $-1.0 \mathrm{~V}$. The most effective accumulation was observed under accumulation potential of about $E_{\text {acc }}=-0.80 \mathrm{~V}$ and hence, this value was used in the further measurements.

As mentioned previously, the sensitivity of the method depends markedly on the properties of the potential waveform applied in the course of the stripping step. Accordingly, an attempt was made to optimize the properties of the SW excitement signal such as SW amplitude $E_{\text {sW }}$ (the height of the potential pulses), SW frequency $f$ (the duration of single potential pulse), and scan increment $\mathrm{d} E$ (the step of the staircase potential ramp at which potential pulses of square shape are superimposed).

The peak current increases strongly by increasing the $\mathrm{SW}$ amplitude from 2 to $50 \mathrm{mV}$. This phenomenon has already been predicted by the theory of SWV regarding a totally irreversible redox process, which proceeds from an immobilized state of the reactant.

As the amplitude becomes higher than $50 \mathrm{mV}$, the peak current reaches a maximum value forming a plateau on the $I_{\mathrm{p}}-E_{\mathrm{sw}}$ function (see curve 1 in Fig. 4). The peak potential shifts in positive direction within the interval $2 \mathrm{mV} \leq E_{\mathrm{sw}} \leq 150 \mathrm{mV}$. However, the amplitude also influences the shape of the voltammetric response, causing the SW peak to widen by the increase of the amplitude. The ratio $I_{\mathrm{p}} / \Delta E_{\mathrm{p} / 2}$ gains a maximum value for $\mathrm{Esw}=25 \mathrm{mV}$, consequently this value was selected as an optimal for analytical measurements.

The signal frequency was varied over the interval from 10 to $120 \mathrm{~Hz}$. It was observed that the frequency affects both the position and height of the SW response. A linear relationship between $E_{\mathrm{p}}$ (peak potential) and logarithm of the frequency was observed with a constant slope of $\Delta E_{\mathrm{p}} / \Delta \log (f)=-30.1 \mathrm{mV}$. At the same time, the peak current increases linearly with the SW frequency, which is typical for redox reaction occurring on the electrode surface via adsorbed reactant. The half-peak width is insensitive on the signal frequency. Thus, SW frequency of $f=120 \mathrm{~Hz}$ was considered as an optimal value for further quantitative analysis.

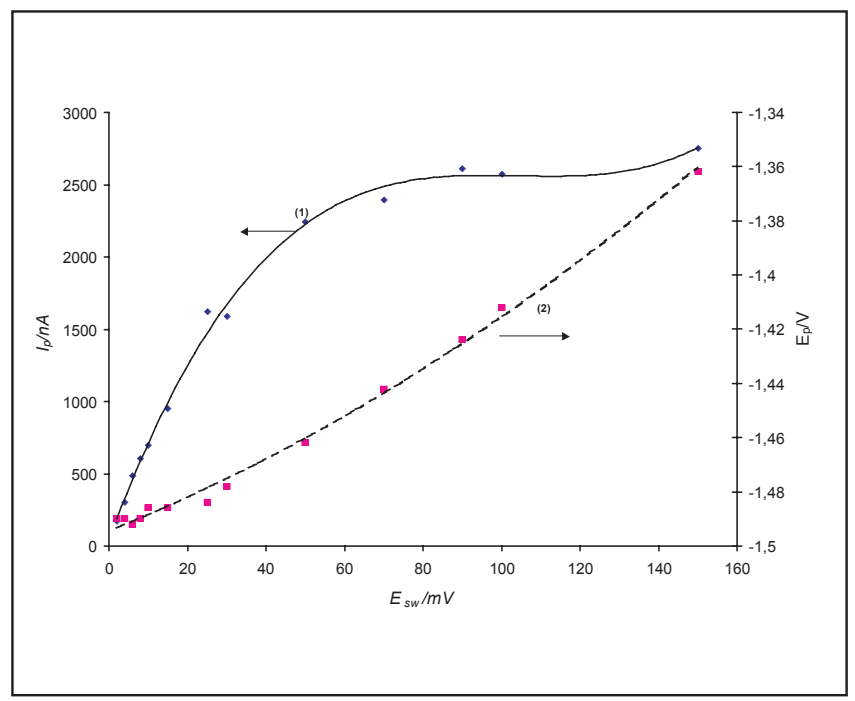

Fig. 4. Dependence of the peak currents (curve 1) and peak potentials (curve 2 ) on the signal amplitude. Experimental conditions were: $f=100 \mathrm{~Hz}, \mathrm{~d} E=2 \mathrm{mV}$, $E_{\text {acc }}=-0.8 \mathrm{~V}, t_{\text {acc }}=15 \mathrm{~s}, \mathrm{c}($ glyc. $)=5 \times 10^{-6} \mathrm{~mol} / \mathrm{L}$, supporting electrolyte $0.1 \mathrm{~mol} / \mathrm{L} \mathrm{KI}$ buffered to $\mathrm{pH} 4.7$.

The scan increment exhibits rather similar effect to the voltammetric response as that of SW amplitude and consequently those results will be not repeated hereafter. The value of $\mathrm{d} E=8 \mathrm{mV}$ was selected as most relevant for quantitative measurements.

Therefore, the following set of experimental conditions are proposed for quantitative determination of GA: supporting electrolyte $0.1 \mathrm{~mol} / \mathrm{L} \mathrm{KI}$ buffered with citrate buffer to $\mathrm{pH}=4.7$, deposition potential $E_{\text {acc }}=-0.8 \mathrm{~V}, \mathrm{SW}$ frequency $f=120 \mathrm{~Hz}, \mathrm{SW}$ amplitude $E_{\mathrm{sw}}=25 \mathrm{mV}$, and scan increment $\mathrm{d} E=8 \mathrm{mV}$. The duration of the deposition step depends on the analyte concentration range.

A calibration curve of GA was recorded in $0.1 \mathrm{KI}$ buffered to $\mathrm{pH}=4.7$, over the concentration range from $5 \times 10^{-7} \mathrm{~mol} / \mathrm{L}$ to $7 \times 10^{-6} \mathrm{~mol} / \mathrm{L}$. The other experimental conditions were: $f=100 \mathrm{~Hz}, \mathrm{~d} E=8 \mathrm{mV}, E_{\mathrm{sw}}=25 \mathrm{mV}, E_{\text {acc }}$ $=-0.8 \mathrm{~V}$ and $t_{\mathrm{acc}}=15 \mathrm{~s}$. The line is associated with a linear regression correlation coefficient of $\mathrm{R}=0.9992$.

To estimate the accuracy of the proposed adsorptive voltammetric method, a recovery analysis was undertaken and the corresponding results are listed in Table 3. 
Table 3. Results of recovery analysis obtained by standard addition method. Experimental conditions were: $f=100 \mathrm{~Hz}, E_{\mathrm{sw}}=25 \mathrm{mV}$, $\mathrm{d} E=2 \mathrm{mV}$, supporting electrolyte $0.1 \mathrm{~mol} / \mathrm{L} \mathrm{KI}$ buffered to $\mathrm{pH} 4.7$.

\begin{tabular}{cccc}
\hline \hline Sample & Added (mol/L) & Found $(\mathrm{mol} / \mathrm{L})$ & $\begin{array}{c}\text { Recovery } \\
(\%)\end{array}$ \\
\hline $\begin{array}{c}\text { Glycyrrhizinic } \\
\text { acid - } \\
\text { spray }\end{array}$ & $4.97 \times 10^{-6}$ & $4.80 \times 10^{-6}$ & 96.58 \\
& $5.9 \times 10^{-6}$ & $6.06 \times 10^{-6}$ & 102.71 \\
& $9.95 \times 10^{-6}$ & $10.40 \times 10^{-6}$ & 104.50 \\
\hline
\end{tabular}

For recovery analysis, the standard addition method and the Hon equation were utilized. The Hon formula for determination of the sample concentration reads:

$$
c_{s}=\frac{c_{s t} \cdot V_{s t} \cdot I_{p, s}}{I_{p, s t} \cdot\left(V_{\text {cell }}+V_{s t}\right)-I_{p, s} \cdot V_{\text {cell }}}
$$

where $c_{\mathrm{s}}$ is sample concentration, $c_{\mathrm{st}}$ is concentration of the standard addition, $V_{\mathrm{st}}$ is volume of the standard addition, $I_{\mathrm{p}, \mathrm{s}}$ is current associated with the sample, $I_{\mathrm{p}, \mathrm{st}}$ is current of the standard addition, and $V_{\text {cell }}$ is volume of the electrolyzing solution.

\section{Determination of glycyrrhizinic acid by HPLC method}

A reversed phase HPLC procedure was developed as a comparative method for determination of GA in pharmaceutical preparation. GA was well resolved from the other formulation components using the previous established selective chromatographic conditions. The retention time of glycyrrhizinic acid was found to be approximately 4.8 minutes (Fig. 5).

Peak purity of glycyrrhizinic acid in the sample has been established with software program Waters Millennium 32 by comparing the purity angle $(0.119)$ with purity threshold (0.269).

The dependence of the GA peak area on the concentration of the injected solution was linear over the investigated range of 10 to $500 \mu \mathrm{g} / \mathrm{ml}$ with a linear regression correlation coefficient of $\mathrm{R}=0.9994$.

The accuracy of the chromatographic procedure was confirmed by the method of standard addition (Table 4).

The recovery values of GA determinations range from 99.1 to $101.77 \%$ confirming that HPLC method is both quantitative and accurate.

The results of GA determination in pharmaceutical preparation obtained by square-wave voltammetry and high-pressure liquid chromatography are given in Table 5 .

As it can be seen, the results obtained by voltammetric and HPLC method are precise, accurate and reproducible.

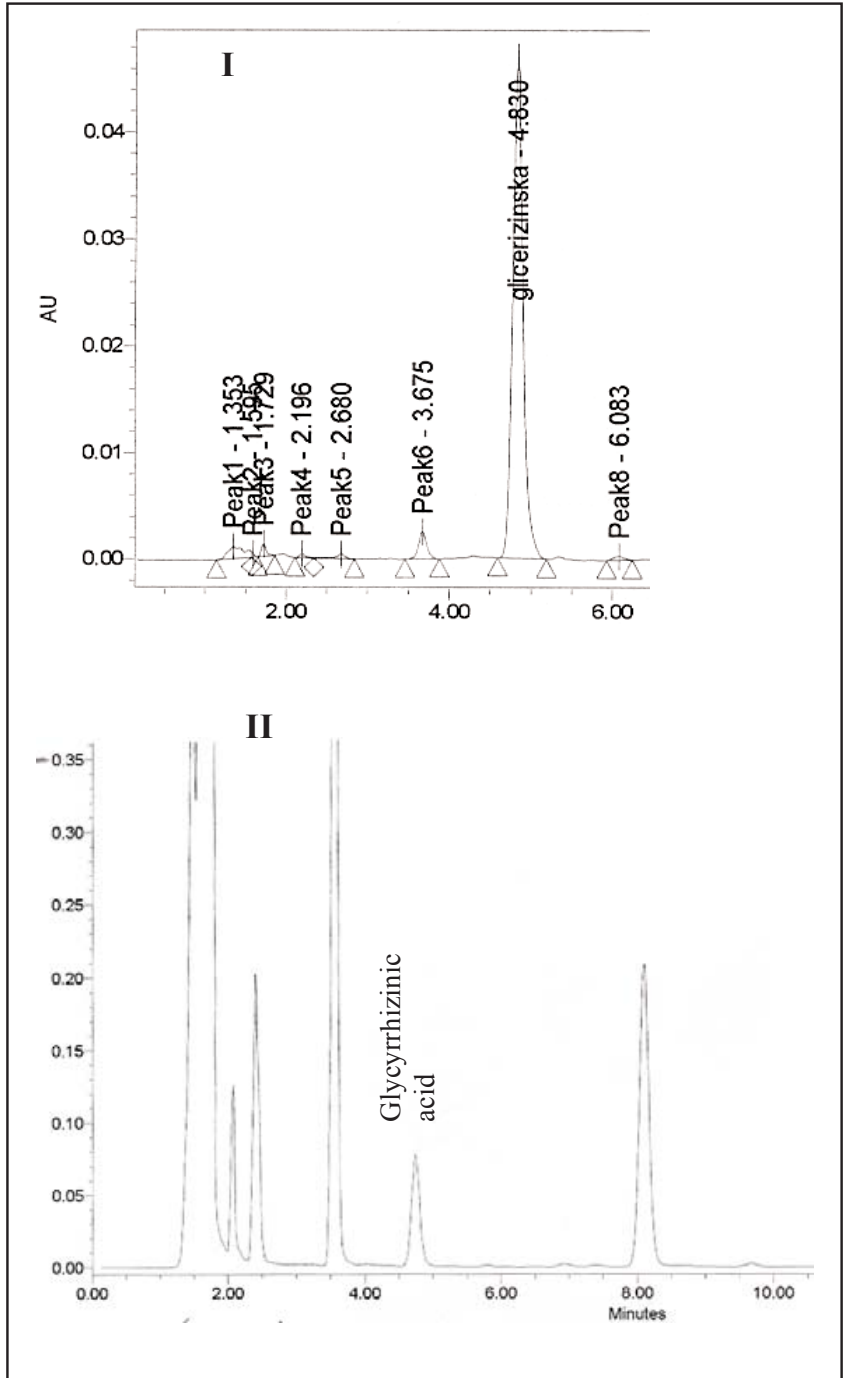

Fig. 5. Chromatograms of: I - glycyrrhizinic acid, standard substance $(100 \mu \mathrm{g} / \mathrm{ml})$, II - sample (glycyrrhizinic acid $\sim 100 \mu \mathrm{g} / \mathrm{ml}$ ).

Table 4. Results of glycyrrhizinic acid determination by method of standard addition, for estimating the accuracy of the HPLC method

\begin{tabular}{cccc}
\hline \hline Sample & Added $(\mathrm{mg} / \mathrm{ml})$ & Found $(\mathrm{mg} / \mathrm{ml})$ & $\begin{array}{c}\text { Recovery } \\
(\%)\end{array}$ \\
\hline & - & 0.9953 & - \\
$\begin{array}{c}\text { Glycyrrhizinic } \\
\text { acid - }\end{array}$ & 0.25 & 1.2341 & 99.10 \\
spray & 0.50 & 1.4733 & 98.53 \\
& 1.00 & 2.0306 & 101.77 \\
\hline
\end{tabular}

Table 5. Results of glycyrrhizinic acid determination in sample (spray) by square-wave voltammetry and high-pressure liquid chromatography

\begin{tabular}{ccccc}
\hline Method & $\begin{array}{c}\text { Declared } \\
(\mathrm{mg} / \mathrm{ml})\end{array}$ & $\begin{array}{c}\text { Determined } \\
(\mathrm{mg} / \mathrm{ml})\end{array}$ & $\begin{array}{c}\text { RSD } \\
(\%)\end{array}$ & $\begin{array}{c}\text { Recovery } \\
(\%)\end{array}$ \\
\hline SWV & 1.0 & 1.037 & 4.84 & 103.7 \\
HPLC & & 0.993 & 1.54 & 99.3 \\
\hline
\end{tabular}




\section{Conclusion}

A new adsorptive stripping square-wave voltammetric method for quantitative determination of glycyrrhizinic acid in pharmaceutical preparations is proposed. The method is simple, fast and precise. The voltammetric measurement itself takes a few seconds. Moreover, it is important to emphasize that the proposed method could be applied without previous treatment of the original preparation. The proposed method is also attractive due to the low cost of the electrochemical instrumentation. The conditions for quantification of GA applying high-pressure liquid chromatography are also established. The precision, accuracy and reproducibility of the voltammetric method are comparable to those of HPLC method and both may be applied for routine analysis and determination of glycyrrhizinic acid in pharmaceutical formulations.

\section{References}

1. M. Wichtl, Herbal Drugs, Medpharm Scientific Publishers, Stuttgart, 1994.

2. A.N. Carol, A.A. Linda and J.P. David, Herbal Medicines, The Pharmaceutical Press, London,1996.

3. M. Itoh, N. Asakawa, Y. Hashimoto, M. Ishibashi and H. Miyazaki, J. Pharm. Soc. Jpn., 12, 1150-1154 (1985).
4. S.S. Nina, Pharmaceutical Biomedical Analysis, 5, 289-293 (1987).

5. G. Lu and J. Liu, Yaowu-Fenxi-Zazhi, 8, 137-139 (1988).

6. D.H. Yan, Yaowu-Fenxi-Zazhi, 13, 381-383 (1993).

7. E. Hahn-Deinstrop, Thin-Layer chromatography in German Pharmacopeia, Dtsch. Apoth. Ztg., 29, 26-39, (1995).

8. X.J. Cui, Y.C. Chi, Y.H. Jin, W.L Dong and J. Zhang, YaowuFenxi-Zazhi, 16, 323-324 (1996).

9. R. Matissek and P. Spoeer, Dtsch-Lebensm-Rundsch., 92, 381-387 (1996).

10. P. Wang, S.F.Y. Li and H.K. Lee, J. Chromatogr A., 811, 219-224 (1998).

11. H. Song and W. Wang, Yaowu-Fenxi-Zazhi, 7, 108-110 (1987).

12. W. Guo, J.F. Song, G. Chen and Y. Wang, Fenxi-Shiyanshi, 15, $51-54$ (1996).

13. J. Mau, Fenxi-Huaxue., 16, 188-189 (1988).

14. M. Mizugaki, K. Itoh, M. Hayasaka, S. Ishiwata, S. Nozaki, N. Nagata, K. Hanadate and N. Ishida, J. Immunoassay, 15, 21-34 (1994).

15. T. Kitagawa, Z. Yang, G. Bai, K. Fujiwara, A. Akahori, / S. Sonoi and S.Kondo, Biol-Pharm-Bull., 20, 211-216 (1997).

16. W. Joseph, In Electroanalytical Chemistry, A.J.Bard (Ed.), Vol. 16, Dekker, New York, 1989.

17. J. Osteryoung, J.J. O’Dea, In Electroanalytical Chemistry, A.J.Bard (Ed.), Vol. 14, Dekker, New York, 1986.

18. L.A. Baltina, O.B. Flechter, Z.M. Putieva, R.M. Kondratenko, L.V. Krasnova and G.A. Tolstikov, Khim. Farm. Zh., 30, 47-49 (1996).

\title{
Резиме
}

\section{Квантитативно определување на глициризинска киселина со квадратно-бранова волтаметрија и течна хроматографија под висок притисок}

\author{
Анета Димитровска 1 , Валентин Мирчевски², Светлана Кулеванова ${ }^{1}$

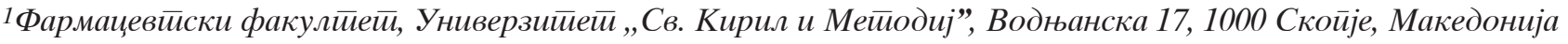

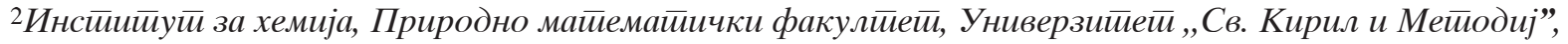 \\ Архимедова 5, Р.О. Вох 162, 1000 Скойје, Македонија
}

Клучни зборови: глицеризинска киселина, квадратно-бранова волтаметрија, течна хроматографија под висок притисок

Развиен е метод на квадратно-бранова волтметрија и течна хроматографија под висок притисок за директно определување на глициризинската киселина во дозиран фармацветски препарат, што се користи против вирусни инфекции. Глициризинската киселина е електрохемиски активна сусптанција, што подлежи на иреверзибилна редукција на површината на живината електрода, во воден медиум. Редокс својствата на глициризинската киселина беа целосно проучени со примена на квадратно-брановата волтаметрија, како една од најефикасните електроаналитички техники. Волтаметрискиот одговор главно зависи од рН на средината, составот на основниот електролит, како и од параметрите на ексцитирачкиот сигнал. Исто така, утврдено е дека волтаметрискиот одговор е силно зависен од времето на акумулација и од потенцијалот, кои укажуваат на значителна адсорпција на глициризинската киселина на површината на живината електрода.

Методот на реверзно-фазна течна хроматографија под висок притисок беше развиен, главно за споредба и потврдување на резултатите добиени со волтаметрискиот метод. 